Supporting Information for:

\title{
Small Titanium Oxo-Clusters: Primary Structures of Titanium(IV) in Water
}

Guanyun Zhang, Jie Hou, Chen-Ho Tung and Yifeng Wang*

Key Lab of Colloid and Interface Science of the Education Ministry, Department of Chemistry and Chemical Engineering, Shandong University, Ji'nan 250199, P. R. China

Table of contents

\section{Experimental Section}

Table S1. Crystallographic data summary

Table S2. Summarized bond lengths $(\AA)$ and bond angles $\left({ }^{\circ}\right)$

Table S3. BVS calculations for $\mathrm{O}$ atoms in compound $\mathbf{1 .}$

Table S4. BVS calculations for $\mathrm{O}$ atoms in compound 2.

Table S5. BVS calculations for $\mathrm{O}$ atoms in compound $\mathbf{3}$.

Figure S1. Powder XRD pattern of $\mathbf{1 .}$

Figure S2. Powder XRD pattern of 2.

Figure S3. Powder XRD pattern of 3.

Figure S4. Structures of (left) $\mathrm{TiOSO}_{4} \cdot \mathrm{H}_{2} \mathrm{O}$ and (right) $\mathrm{TiOSO}_{4}$.

Figure S5. XRD pattern.

Vibrational Spectra.

Figure S6. IR of 1, 2, 3 and $\mathrm{TiOSO}_{4}$.

Figure S7. Raman spectra of 1, 2, 3 and $\mathrm{TiOSO}_{4}$.

Figure S8. DRS of $\mathbf{1}, \mathbf{2}, 3$ and $\mathrm{Ti}_{12} \mathrm{O}_{16}\left(\mathrm{OPr}^{i}\right)_{16}$.

\section{References}




\section{EXPERIMENTAL SECTION}

Materials. Titanyl sulfate (93\%) was obtained from Aladdin Industrial Inc. Analytical grade $\mathrm{TiCl}_{4}$ and $\mathrm{CsCl}$ were obtained from Xiya Reagent $\mathrm{Co}$. All other materials were purchased from commercial sources and used as received. All solutions were prepared using 18.25 $\mathrm{M} \Omega$ deionized water.

Instruments. Single crystal X-ray diffraction data were collected using a Bruker SMART APEX II diffractometer with graphite-monochromated Mo-K $\alpha$ radiation source $(\lambda=0.71073 \AA)$ at $173 \mathrm{~K}$. Xray powder diffractions were conducted with a Bruker D8 Advance X-ray diffraction instrument using $\mathrm{Cu}-\mathrm{K} \alpha$ radiation $(40 \mathrm{KV}$ and $40 \mathrm{~mA})$ in the scanning angle $(2 \theta)$ range of $5-50^{\circ}$. Fourier Transformation Infrared spectra (FTIR) were recorded using a PerkinElmer Spectrum Two IR Spectrometer. UV-vis diffuse reflectance spectra (DRS) were measured on a Shimadzu UV2550 spectrophotometer with $\mathrm{BaSO}_{4}$ as the reflectance standard. Raman spectra were obtained on a NEXUS 670 FT-IR Raman spectrometer with $532 \mathrm{~nm}$ excitation. Elemental analyses $(\mathrm{C}, \mathrm{H}$, and $\mathrm{N})$ were measured on a FLASH EA1112 elemental analyzer. Elemental analyses of Ti was performed using a spectrophotometric method and confirmed with energy dispersive spectroscopy (EDS) equipped in a Hitachi S-4800 scanning electron microscope, with $\mathrm{K}_{2} \mathrm{TiO}\left(\mathrm{C}_{2} \mathrm{O}_{4}\right)_{2} \cdot 2 \mathrm{H}_{2} \mathrm{O}$ as an external standard.

Colorimetric determination of Ti\%. Quantitative determination of titanium(IV) is based on the characteristic UV-vis absorption of the yellow pertitanic acid complex ${ }^{4}$ of $\mathrm{Ti}$ (IV) and $\mathrm{H}_{2} \mathrm{O}_{2}$ formed in acid aqueous solution. In a volumetric flask $(50 \mathrm{~mL})$, the solid sample is dissolved in $25 \mathrm{~mL}$ of $50 \% \mathrm{v} / \mathrm{v}$ $\mathrm{H}_{2} \mathrm{SO}_{4}$. Then aqueous solutions of $8.0 \%\left(\mathrm{NH}_{4}\right)_{2} \mathrm{SO}_{4}(5.0 \mathrm{~mL})$ and $3.0 \% \mathrm{H}_{2} \mathrm{O}_{2}(8.0 \mathrm{~mL})$ are added. Water is then filled to the calibration mark of the flask. The absorbance of the resultant yellow solution at 408 $\mathrm{nm}$ is used to quantify concentration of Ti(IV) according to a pre-defined calibration curve using $\mathrm{K}_{2} \mathrm{TiO}\left(\mathrm{C}_{2} \mathrm{O}_{4}\right) \cdot 2 \mathrm{H}_{2} \mathrm{O}$ as the authentic substance.

One-pot synthesis of $\left.\mathrm{Cs}_{2}\left[\mathrm{Ti}_{3}\left(\mu_{2}-\mathrm{O}\right)_{3}\left(\mathrm{OH}_{2}\right)_{4} \mathrm{Cl}\right]_{8}\right] \cdot 4 \mathrm{CsCl} \quad$ (1) and $\mathrm{Cs}_{2}\left[\mathrm{Ti}_{4}\left(\mu_{2}-\right.\right.$ $\left.\mathrm{O}_{4}\left(\mathrm{OH}_{2}\right)_{6} \mathrm{Cl}_{2}\left(\mathrm{SO}_{4}\right)_{4}\right] \cdot \mathbf{4 C s C l} \cdot \mathbf{H C l}$ (2). Titanyl sulfate was dissolved in water to make a $20 \%(\mathrm{w} / \mathrm{w})$ solution. The solution was filtered if not quite clear. Then in $20 \mathrm{~mL}$ of the filtrate $2 \mathrm{M} \mathrm{CsCl}$ was made. A few seconds after dissolution of $\mathrm{CsCl}$, a greenish precipitate formed and was collected by filtration. $\mathrm{HCl}$ $(1.5 \mathrm{M})$ was used to dissolve the precipitate and afterwards $0.5 \mathrm{M} \mathrm{CsCl}$ was added. After equilibration for 2-3 hours, the mixture was filtered through a $0.22 \mu \mathrm{m}$ membrane filter. The filtrate was allowed to evaporate slowly under ambient conditions (ca. $20^{\circ} \mathrm{C}$ ). After a few days two type of greenish block crystals formed and identified by FTIR.

Optimized synthesis of 2 . The precipitate in the above procedure was dissolved in $3 \mathrm{M} \mathrm{HCl}$ and afterwards $\mathrm{CsCl}$ was added to reach $0.5 \mathrm{M}$. Then the solution was filtered again with $0.22 \mathrm{um}$ membrane filter. The resultant clear filtrate was allowed to evaporate slowly under ambient conditions (ca. $20^{\circ} \mathrm{C}$ ). After several weeks, tiny greenish block crystals began to appear. However, large amounts of spherical crystals (the crude product) might form if evaporation is too fast. The product was collected by filtration and air dried under suction for 10 - 20 minutes (3.2 g, yield 30\% based on Ti). Anal. Calcd: Ti, 10.7\%. Found: Ti, $(10.8 \pm 0.3) \%$.

Optimized synthesis of 1 . To $9.0 \mathrm{~mL}$ of $1.0 \mathrm{M} \mathrm{TiCl}_{4}$ aqueous solution $\mathrm{CsCl}$ was added to make [CsCl] $=1.0 \mathrm{M}$. After equilibration for 2-3 hours, the mixture was filtered through a $0.22 \mu \mathrm{m}$ membrane filter. The filtrate was allowed to evaporate slowly under ambient conditions (ca. $20{ }^{\circ} \mathrm{C}$ ). After about two weeks greenish crystals formed. They were collected by filtration and air dried under suction for $10-20$ minutes (1.5 g, yield 35\% based on Ti). Anal. Calcd: Ti, 9.7\%. Found: Ti, $(10.0 \pm 0.5) \%$.

Synthesis of $\left[\mathrm{Ti}_{4} \mathrm{O}_{4}\left(\mathrm{OH}_{2}\right)_{8}\left(\mathrm{SO}_{4}\right)_{4}\right] \cdot 2 \mathrm{TEAC} \cdot\left(\mathrm{H}_{2} \mathrm{SO}_{4}\right) \cdot \mathbf{1 0 H}_{2} \mathrm{O}(3)$. A mixture of $\mathrm{TiCl}_{4}(1.0 \mathrm{M} ; 10 \mathrm{~mL})$, $\mathrm{H}_{2} \mathrm{SO}_{4}(3.0 \mathrm{M})$ and tetraethylammonium chloride (TEAC; $\left.1.0 \mathrm{M}\right)$ was stirred for $24 \mathrm{~h}$ under ambient conditions. After filtration, slow evaporation of the filtrate afforded colorless block crystals of compound 
3 in three weeks (based on Ti). The product was collected by filtration and air-dried with suction for 10 minutes. Alternatively, crystals of lower quality can be obtained by rapid evaporation under ambient conditions (2 days; yield 80\% based on Ti). Anal. Calcd (\%): Ti, 13.8; C, 13.8; N, 2.0; H, 5.6. Found (\%): Ti, 13.1; C, 14.1; N, 1.9; H, 5.1.

X-ray single crystal crystallography. Single crystals with appropriate dimensions were collected from the mother liquor, coated with high vacuum grease (Dow Corning Corporation), and transferred to a stream of cold $\mathrm{N}_{2}$ on the diffractometer as quickly as possible to prevent decomposition due to solvent loss. Data were collected on a Bruker SMART APEX II diffractometer with a CCD area detector using Mo $\mathrm{K} \alpha$ radiation $(\lambda=0.71073 \AA)$ at $173 \mathrm{~K}$. Indexing was processed with APEX2 through difference vectors method. Data integration and reduction were done using SaintPlus 6.01 ${ }^{2}$. Absorption correction was performed using the multi-scan method with $\mathrm{SADABS}^{3}$. Structure solution and refinement were performed using the least-square method implemented in Olex2 v1.2 ${ }^{4}$. Crystallographic data are summarized in Table S1. Hydrogen atoms were not included for the terminal water/hydroxide ligands nor for the solvent water because they could not be positively identified.

More comments on compound 3. When structure of compound 3 was solved, the TEA cations and crystal water molecules could not be located. "Squeeze" was applied after other work had been finished completely. Before "squeeze", R1 was ca. 11\%. Then "squeeze" gave a residue electron density of $865 \mathrm{e}$ per cell. Based on the elementary analysis results, we then added $8 \mathrm{TEA}^{+}(600 \mathrm{e})$ and $40 \mathrm{H}_{2} \mathrm{O}(400 \mathrm{e})$ molecules to each unit cell. Further refinements gave a much better R1 value of $6.35 \%$.

Table S1. Crystallographic data summary

\begin{tabular}{|c|c|c|c|}
\hline Compound & 1 & 2 & 3 \\
\hline Empirical formula & $\mathrm{H}_{8} \mathrm{Cl}_{12} \mathrm{Cs}_{6} \mathrm{O}_{7} \mathrm{Ti}_{3}$ & $\mathrm{H}_{15} \mathrm{Cl}_{7} \mathrm{Cs}_{6} \mathrm{O}_{26} \mathrm{~S}_{4} \mathrm{Ti}_{4}$ & $\mathrm{C}_{8} \mathrm{H}_{78} \mathrm{Cl}_{2} \mathrm{~N}_{2} \mathrm{O}_{42} \mathrm{~S}_{5} \mathrm{Ti}_{4}$ \\
\hline Formula weight (g/mol) & 1486.56 & 1795.45 & 1392.8756 \\
\hline Crystal system & orthorhombic & monoclinic & triclinic \\
\hline Space group (Nr.) & Fdd 2 & $\mathrm{C} 2$ & P-1 \\
\hline$a(\AA)$ & $16.1626(10)$ & $18.994(5)$ & $13.871(4)$ \\
\hline b $(\AA)$ & $30.975(2)$ & $10.217(3)$ & $13.885(4)$ \\
\hline c $(\AA)$ & $12.1951(8)$ & $11.715(3)$ & $23.400(7)$ \\
\hline$\alpha\left({ }^{\circ}\right)$ & 90 & 90 & $92.679(3)$ \\
\hline$\beta\left(^{\circ}\right)$ & 90 & $114.548(4)$ & $98.013(3)$ \\
\hline$\delta\left({ }^{\circ}\right)$ & 90 & 90 & $90.122(3)$ \\
\hline Volume $\left(\AA^{3}\right)$ & $6116.6(7)$ & $2067.9(10)$ & $4458(2)$ \\
\hline $\mathrm{Z}$ & 8 & 2 & 4 \\
\hline$D_{\text {calc }}\left(\mathrm{g} / \mathrm{cm}^{3}\right)$ & 3.211 & 2.861 & 1.933 \\
\hline Abs. Coeff. $\mu\left(\mathrm{mm}^{-1}\right)$ & 8.871 & 6.677 & 1.167 \\
\hline Temperature $(\mathrm{K})$ & 173 & 173.15 & 173.15 \\
\hline Total reflections & 6943 & 5521 & 42478 \\
\hline $\operatorname{Min}-\max \theta\left(^{\circ}\right)$ & 5.678 to 49.97 & 4.672 to 49.996 & 4.69 to 49.998 \\
\hline Unique reflections & 5531 & 4933 & 15590 \\
\hline Calculated reflection $(\mathrm{I}>2 \sigma)$ & 2179 & 2718 & 7161 \\
\hline $\mathrm{R}_{1}[\mathrm{I}>=2 \sigma]^{\mathrm{a}}$ & 0.0130 & 0.0968 & 0.0635 \\
\hline$w_{2}(\text { all data })^{b}$ & 0.0314 & 0.2660 & 0.1677 \\
\hline $\mathrm{R}_{\text {int }}$ & 0.0178 & 0.0253 & 0.0879 \\
\hline Goodness of fit on $\mathrm{F}^{2}$ & 1.073 & 1.063 & 0.849 \\
\hline Parameters & 129 & 213 & 829 \\
\hline Restraints & 1 & 13 & 208 \\
\hline Largest diff. peak/hole $\left(\mathrm{e} \AA^{-3}\right)$ & $0.56 /-0.77$ & $6.28 /-1.53$ & $1.39 /-1.18$ \\
\hline
\end{tabular}

${ }^{\mathrm{a}} R_{l}=\Sigma \| F($ obs $)-\mid F($ calc $) \| / \Sigma \mid F($ obs $) \mid ;{ }^{\mathrm{b}} \mathrm{wR}_{2}=\left\{\Sigma\left[w\left(F_{o}{ }^{2}-F_{c}{ }^{2}\right)^{2}\right] / \Sigma\left[w\left(F_{0}{ }^{2}\right)^{2}\right]\right\}^{1 / 2}$ 
Table S2. Summarized bond lengths $(\AA)$ and bond angles $\left(^{\circ}\right)$

\begin{tabular}{lllll}
\hline & 1a & 2a & 3a & ref. values \\
\hline $\mathrm{d}(\mathrm{Ti}-\mathrm{Cl})$ & $2.34-2.49$ & 2.31 & - & 2.41 in $\mathrm{Ti}_{2} \mathrm{Cl}_{2}\left(\mathrm{OPr}^{\mathrm{i}}\right)_{4}\left(\mathrm{HOPr}^{\mathrm{i}}\right)_{2}{ }^{\text {a }}$ ref. 5 \\
$\mathrm{~d}\left(\mathrm{Ti}-\mathrm{OSO}_{3}\right)$ & - & $1.89-1.99$ & $1.94-2.00$ & $1.95-2.05$ in $\mathrm{TiOSO}_{4}$, ref. $^{6}$ \\
$\mathrm{~d}\left(\mathrm{Ti}-\mathrm{O}_{\mu 2}\right)$ & $1.81-1.82$ & $1.78-1.91$ & $1.80-1.82$ & $1.79-1.86$ in $\mathrm{Ti}_{8} \mathrm{O}_{12}\left(\mathrm{OH}_{2}\right)_{24}{ }^{8+}$, ref. 7 \\
$\mathrm{~d}\left(\mathrm{Ti}_{-}-\mathrm{OH}_{2}\right)$ & $2.14-2.15$ & $2.10-2.25$ & $2.08-2.10$ & $2.08-2.16$ in $\mathrm{Ti}_{8} \mathrm{O}_{12}\left(\mathrm{OH}_{2}\right)_{24}{ }^{8+}$, ref. 7 \\
$\mathrm{~d}(\mathrm{Ti} \cdots \mathrm{Ti})$ & $3.45-3.47^{\mathrm{b}}$ & $3.43-3.53^{\mathrm{b}}$ & $3.44-3.47^{\mathrm{b}}$ & $3.52-3.62$ in $\mathrm{Ti}_{8} \mathrm{O}_{12}\left(\mathrm{OH}_{2}\right)_{24}{ }^{8+}$, ref. 7 \\
$\angle \mathrm{TiO}_{\mu 2} \mathrm{Ti}$ & ca. 144 & ca. 144 & $143-147$ & $152-156$ in $\mathrm{Ti}_{8} \mathrm{O}_{12}\left(\mathrm{OH}_{2}\right)_{24}{ }^{8+}$, ref. 7
\end{tabular}

${ }^{a}$ Not available for aqueous isolated compounds. ${ }^{b}$ Distance between the $\mathrm{O}_{\mu 2}$-bridged Ti.

Table S3. BVS calculations for O atoms in compound $\mathbf{1 .}$

\begin{tabular}{llllllll}
\hline $\begin{array}{l}\boldsymbol{\mu}_{2} \text {-O / total } \\
\text { valence }\end{array}$ & bonded atoms & $\begin{array}{l}\text { distance } \\
(\mathbf{\AA})\end{array}$ & BVS & aqua-O & $\begin{array}{l}\text { bonded } \\
\text { atoms }\end{array}$ & $\begin{array}{l}\text { distance } \\
(\mathbf{\AA})\end{array}$ & BVS \\
\hline O1/1.958 & Ti1 & 1.823 & 0.979 & O2 & Ti1 & 2.143 & 0.412 \\
& Ti1 & 1.823 & 0.979 & O3 & Ti2 & 2.147 & 0.408 \\
O9/2.006 & Ti1 & 1.814 & 1.003 & & & & \\
& Ti1 & 1.814 & 1.003 & & & & \\
$09 / 1.958$ & Ti2 & 1.817 & 0.995 & & & & \\
& Ti2 & 1.817 & 0.995 & & & & \\
\hline
\end{tabular}

Table S4. BVS calculations for O atoms in compound 2.

\begin{tabular}{|c|c|c|c|c|c|c|c|}
\hline $\begin{array}{l}\mu_{2}-\mathrm{O} / \text { total } \\
\text { valence }\end{array}$ & $\begin{array}{l}\text { bonded } \\
\text { atoms }\end{array}$ & $\begin{array}{l}\text { distance } \\
(\AA)\end{array}$ & BVS & aqua-O & $\begin{array}{l}\text { bonded } \\
\text { atoms }\end{array}$ & $\begin{array}{l}\text { distance } \\
\text { (̊) }\end{array}$ & BVS \\
\hline \multirow{2}{*}{ O1/1.861 } & Ti1 & 1.783 & 1.090 & O3 & Ti2 & 2.121 & 0.437 \\
\hline & Ti2 & 1.911 & 0.771 & $\mathrm{O} 4$ & Ti2 & 2.099 & 0.464 \\
\hline \multirow{2}{*}{$\mathrm{O} 2 / 2.036$} & Ti1 & 1.838 & 0.940 & O5 & Ti1 & 2.255 & 0.304 \\
\hline & Ti2 & 1.781 & 1.096 & & & & \\
\hline
\end{tabular}

Table S5. BVS calculations for O atoms in compound 3.

\begin{tabular}{llllllll}
\hline $\begin{array}{l}\boldsymbol{\mu}_{2} \text {-O / total } \\
\text { valence }\end{array}$ & $\begin{array}{l}\text { bonded } \\
\text { atoms }\end{array}$ & $\begin{array}{l}\text { distance } \\
(\mathbf{\AA})\end{array}$ & BVS & aqua-O & $\begin{array}{l}\text { bonded } \\
\text { atoms }\end{array}$ & $\begin{array}{l}\text { distance } \\
(\AA)\end{array}$ & BVS \\
\hline \multirow{2}{*}{ 01/2.015 } & Ti1 & 1.802 & 1.036 & O5 & Ti1 & 2.091 & 0.474 \\
& Ti2 & 1.823 & 0.979 & O6 & Ti1 & 2.101 & 0.462 \\
& Ti2 & 1.809 & 1.016 & O7 & Ti2 & 2.09 & 0.476 \\
O2/2.011 & Ti3 & 1.817 & 0.995 & O8 & Ti2 & 2.1 & 0.463
\end{tabular}




\begin{tabular}{lccccccc} 
O3/2.011 & Ti3 & 1.814 & 1.003 & O9 & Ti3 & 2.095 & 0.469 \\
& Ti4 & 1.812 & 1.008 & O10 & Ti3 & 2.091 & 0.474 \\
& Ti1 & 1.812 & 1.008 & O11 & Ti4 & 2.084 & 0.483 \\
& Ti4 & 1.822 & 0.981 & O12 & Ti4 & 2.084 & 0.483 \\
\hline
\end{tabular}

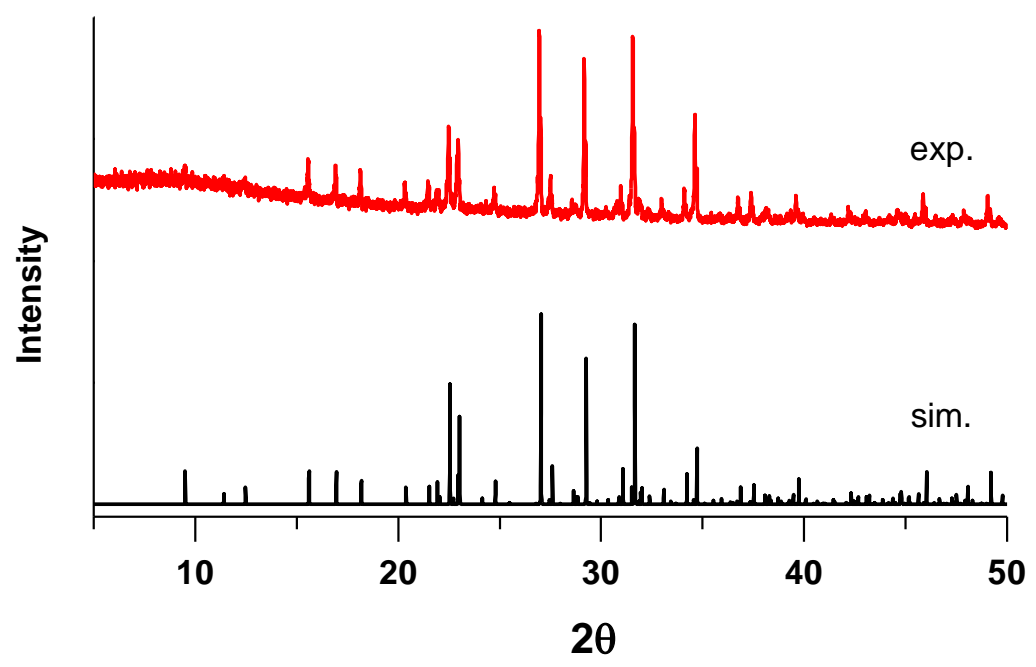

Figure S1. Powder XRD pattern of 1.

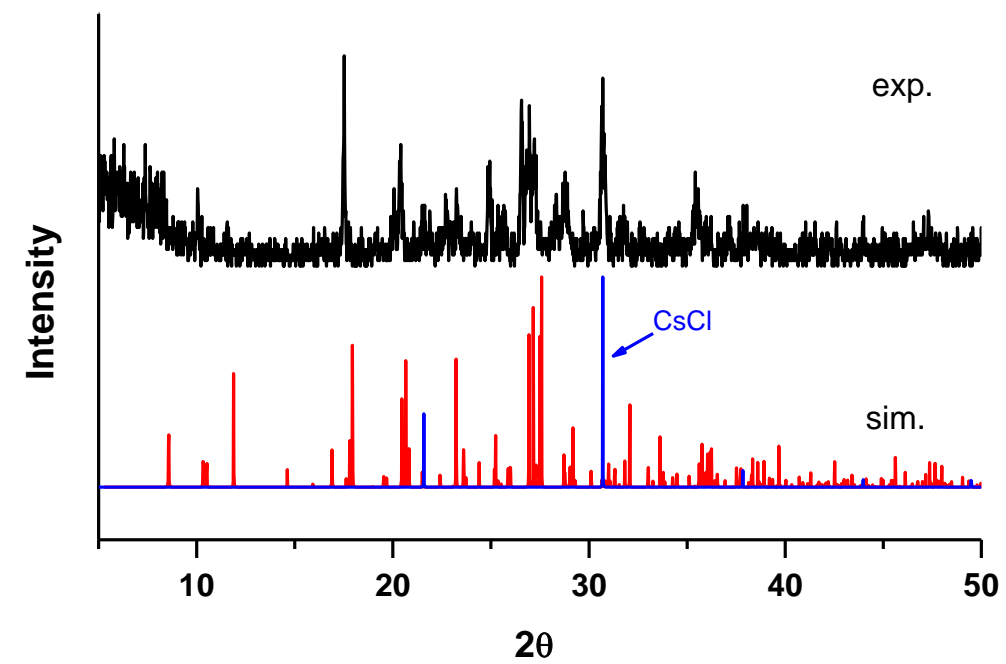

Figure S2. Powder XRD pattern of $\mathbf{2}$. This is obtained by using the spherical crystals obtained by relative fast evaporation of solvent. However, the powder pattern indicates the existence of impurities, e.g., $\mathrm{CsCl}$. 


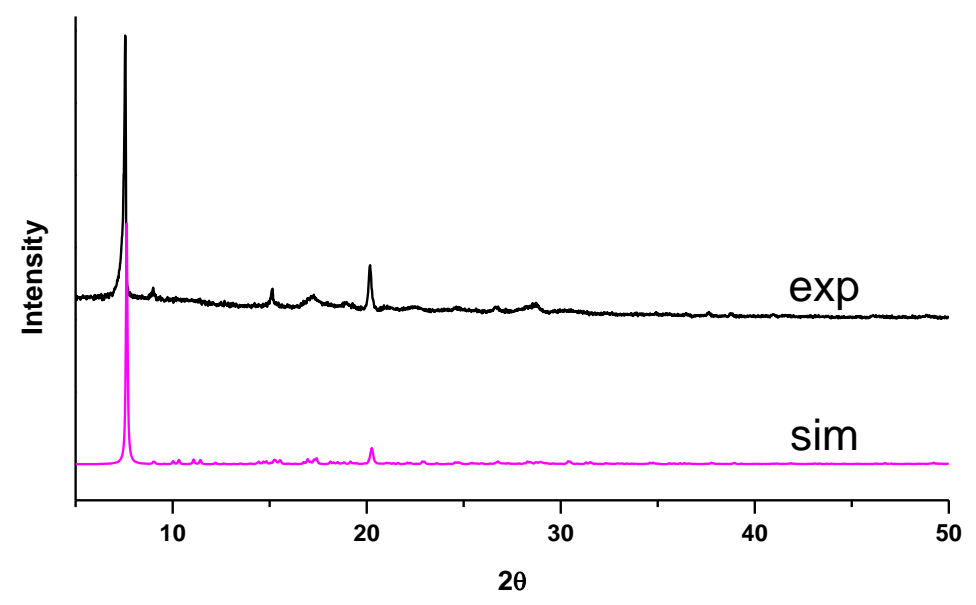

Figure S3. Powder XRD pattern of compound 3.

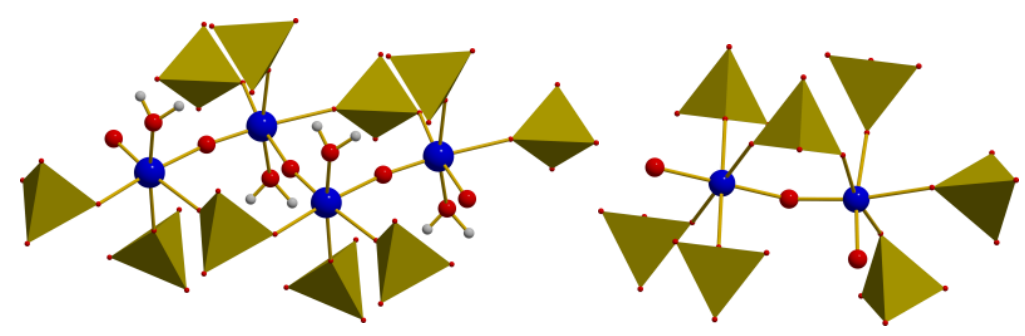

Figure S4. Structures ${ }^{6}$ of (left) $\mathrm{TiOSO}_{4} \cdot \mathrm{H}_{2} \mathrm{O}$ and (right) $\mathrm{TiOSO}_{4}$. The tetrahedrons are $\mathrm{SO}_{4}$ moieties. Color Scheme: Blue, Ti; red, O; grey, $\mathrm{H}$. 


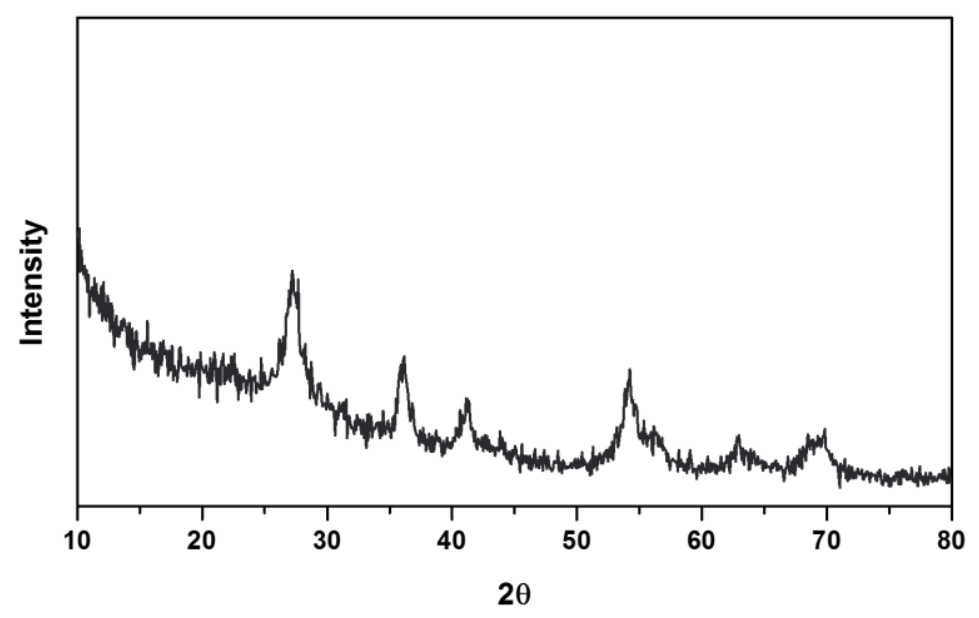

Figure S5. XRD of the precipitate obtained by aging of $1.0 \mathrm{M} \mathrm{TiCl}_{4}$ at room temperature for a month. Data indicate it is rutile $\mathrm{TiO}_{2}$.

Vibrational Spectra. Vibrational spectra including FT-IR (Figure S7) and Raman (Figure S8) are provided herein. By examining the vibrational moieties in the crystal structures, the main features/modes in the spectra are assigned. As shown in Figure S7, the strong and wide peak in the range of 2700-3600 $\mathrm{cm}^{-1}$ and the relatively weaker peaks located at ca. $1620 \mathrm{~cm}^{-1}$ are stretch and bending modes of $\mathrm{OH}_{2}$ groups in compounds 1, 2 and 3. A strong vibrational peak centered at ca. $809 \mathrm{~cm}^{-1}$ for compound 1 should be assigned to a mixture of stretch modes of the Ti-O ${ }_{\mu}$ and Ti- ${ }_{t}$ moieties. The peak centered at ca. $760 \mathrm{~cm}^{-}$ ${ }^{1}$ of 2 and 3 should also be assigned Ti-O moieties. Other peaks like 1232, 1158, 1126, 1019 and $952 \mathrm{~cm}^{-}$ ${ }^{1}$ for 2 and 3 are assigned to stretch modes of $\mathrm{SO}_{4}$ groups, and those located at 672,582 and $477 \mathrm{~cm}^{-1}$ are assigned to bending modes of $\mathrm{SO}_{4}$ groups.

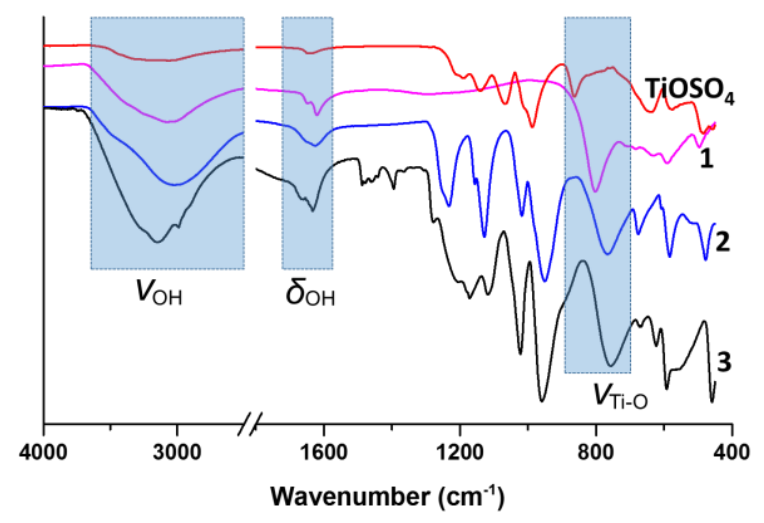

Figure S6. IR of 1, 2, 3 and $\mathrm{TiOSO}_{4}$.

In their Raman spectra, 1, 2, 3 and $\mathrm{TiOSO}_{4}$ all feature a strong peak near $500 \mathrm{~cm}^{-1}$. By comparing their structures, this mode is tentatively assigned to $\mathrm{Ti}-\mathrm{O}_{\mu}$ bond. 


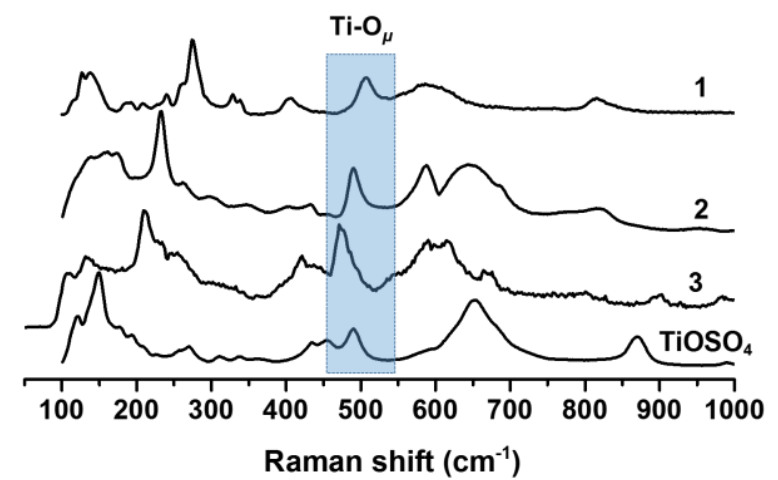

Figure S7. Raman spectra of $\mathbf{1}, \mathbf{2}, \mathbf{3}$ and $\mathrm{TiOSO}_{4}$.

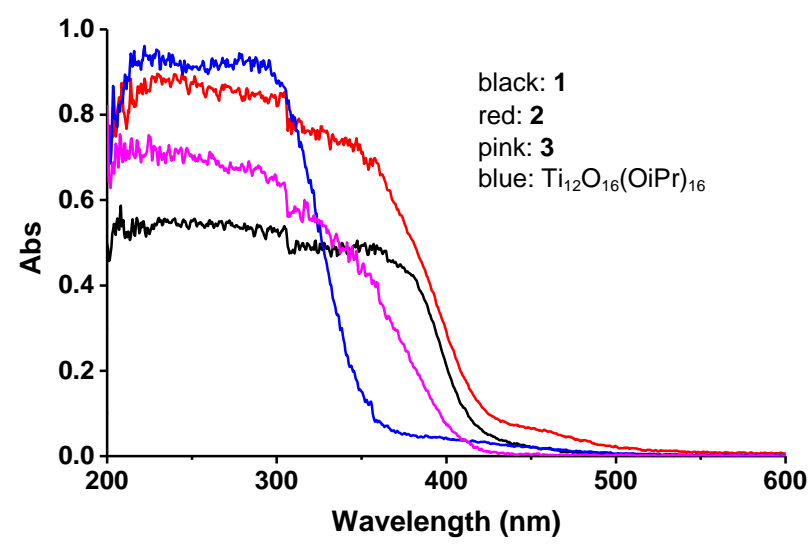

Figure S8. DRS of 1, 2, 3 and $\operatorname{Ti}_{12} \mathrm{O}_{16}\left(\mathrm{OPr}^{i}\right)_{16}{ }^{8}$

\section{References}

(1) Allsopp, C. B.; Leach, W. G. Analyst 1941, 66, 371-372.

(2) SaintPlus: Data Reduction and Correction Program, version 6.22; Bruker AXS: Madison, WI, 2001.

(3) Sheldrick, G. M. SADABS, A Program for Empirical Absorption Correction; University of Göttingen: Göttingen, Germany, 1998.

(4) G. E. Kostakis, V. A. Blatov and D. M. Proserpio, Dalton Trans, 2012, 41, $4634 .$.

(5) Nunes, G. G.; Reis, D. M.; Camargo, P. H. C.; Hitchcock, P. B.; Hörner, M.; Matos, R. M.; Mangrich, A. S.; de Sá, E. L.; Leigh, G. J.; Soares, J. F. J. Braz. Chem. Soc. 2003, 14, 922-929.

(6) Gatehouse, B. M.; Platts, S. N.; Williams, T. B. Acta Crystallographica Section B 1993, 49, 428-435.

(7) Reichmann, M. G.; Hollander, F. J.; Bell, A. T. Acta Crystallogr., Sect. C: Cryst. Struct. Commun. 1987, C43, 1681-1683.

(8) Day, V. W.; Eberspacher, T. A.; Klemperer, W. G.; Park, C. W. J. Am. Chem. Soc. 1993, 115, 8469-8470. 